\title{
TREATMENT OF WASTEWATER FROM CHROME PLATING INDUSTRY BY ION EXCHANGE METHOD
}

\author{
Sujata Karegar ${ }^{1}$, M.Bhargavi ${ }^{2}$, S.V.Divekar ${ }^{3}$ \\ ${ }^{I}$ Post Graduate Student in Environmental Engineering, Dept of Civil Engineering, KLS Gogte Institute of Technology \\ Belgaum-590008, Karnataka, India \\ ${ }^{2}$ Assistant Professor, Dept of Civil Engineering, KLS Gogte Institute of Technology Belgaum-590008, Karnataka, \\ India \\ ${ }^{3}$ Professor, Dept of Chemistry, KLS Gogte Institute of Technology Belgaum-590008, Karnataka, India
}

\begin{abstract}
In the present work an attempt has been made to evaluate the efficiency of removal Cr(VI) from chrome plating industry wastewater by using fresh and reconditioned strong base anion exchanger Tulsion A-27(MP). The Experimental data is evaluated by plotting breakthrough curves and by employing Bohart-Adams Model. The maximum removal (80\%) of Cr(VI) from plating wastewater is obtained at $14 \mathrm{~cm}$ column bed height and flowrate $1 \mathrm{~mL} / \mathrm{min}$ for $1144.39 \mathrm{mg} / \mathrm{L}$ of influent $\mathrm{Cr}(\mathrm{VI})$ concentration. The breakthrough curves for reconditioned and fresh resins indicates that breakthrough occurs early with decrease in bed height, increase in flow rate and influent $\mathrm{Cr}(\mathrm{VI})$ concentration. Regeneration of exhausted resin is also studied by using $2 \mathrm{M} \mathrm{NaCl}$ and $2 \mathrm{M}$ $\mathrm{HCl}$.
\end{abstract}

Keywords: Chromium (VI) removal; Reused Anion-exchange resin; chrome plating industry wastewater;

\section{INTRODUCTION}

The heavy metal hexavalent chromium is one of the major toxic elements because of its carcinogenic nature. The chromium compounds are used in large extent in various industries. And hence to control its harmful effect on environment numerous processes have been used for Chromium (VI) removal [1].

In several parts of the world surface and ground water gets contaminated by $\mathrm{Cr}(\mathrm{VI})$ as chromate. In comparison to Chromium(VI), the Chromium(III) is considered to be less toxic [2]. The problem of pollutants removal from wastewater is growing with developing industries [3]. One of the useful solution for the $\mathrm{Cr}(\mathrm{VI})$ removal from the environment is the treatment of industrial wastewater [4].Various methods used to remove $\mathrm{Cr}(\mathrm{VI})$ from industry wastewater are Chemical precipitation, Ion exchange, Adsorption, Reduction, Solvent extraction, Reverse osmosis [5][6].

Removal of chromium(VI) and recovery of Chromic acid from chrome plating industry wastewater by ion exchange process is challenging.

All the constituents of the plating baths contribute to the wastewater stream either through part drag-out, batch dump or floor spill. Chrome plating baths may contain $\mathrm{Cu}, \mathrm{Ni}, \mathrm{Ag}$, $\mathrm{Zn}, \mathrm{Cd}, \mathrm{Cr}$ (III), Sn, Pb, Fe, ammonia etc. The anionic components likely to be present include chromate, dichromate, borate, fluoride, tartarate, phosphate, chloride, sulfide, sulfate, nitrate etc. Additives used in the plating bath to induce grain refining, deposit brightening, surface leveling etc. these include Mo, Se, As, Co and aldehydes etc, which also contribute to the waste streams. Plating waste also contains trace amount of suspended solids, oil, grease etc [7].

The chrome plating process contributes to water pollution, if the waste water is discharged into the drain, water body, river or lake without treatment. The metal concentration or metal load as $\mathrm{Cr}$ (VI) is of greater worry than the acidity in the provisions of environmental damage. The highly acidic nature of waste water from plating industry can be neutralize by using many chemicals, but which results the high scale sludge. This sludge creates disposal problem and extra cost. Hence, this caused pressure on engineers to search for efficient technique. At present, the research work is directed towards advanced processes to remove hexavalent Chromium along with other trace contaminants [8].

\section{EXPERIMENTAL}

\subsection{Material and Methods}

Tulsion A-27(MP) is purchased from thermax is strong base anion exchange resin whose screen size US Mesh 16-50, particle size $0.3-1.2 \mathrm{~mm}$ (minimum 95\%). The stock solution of $\mathrm{Cr}(\mathrm{VI})$ is prepared by dissolving $\mathrm{K}_{2} \mathrm{Cr}_{2} \mathrm{O}_{7}$ (Merck specialities private Ltd, Mumbai) in double distilled water. All chemicals were of analytical grade. Cary 50Bio UVvisible spectrophotometer(complex is prepared by DPC method) used for the chromium analysis.

Hard Chrome Plating wastewater sample is collected from Electroplating Industry located in Machhe Industrial Area, Belagavi. The sample is diluted in the ratio 1:5 (1144.39 $\mathrm{mg} / \mathrm{L})$ and $1: 7(803.30 \mathrm{mg} / \mathrm{L})$ with distilled water for Ion Exchange column studies. 
Table-1: Parameters of chrome plating industry wastewater

\begin{tabular}{|l|l|l|}
\hline Sl.No. & Parameters & $\begin{array}{l}\text { Concentration of } \\
\text { parameters }\end{array}$ \\
\hline 1 & p H & 2.09 \\
\hline & $\begin{array}{l}\text { Total Suspended } \\
\text { solids }\end{array}$ & $112.0 \mathrm{mg} / \mathrm{L}$ \\
\hline 3 & Iron as Fe & $79.5 \mathrm{mg} / \mathrm{L}$ \\
\hline 4 & Lead as $\mathrm{Pb}$ & $1.095 \mathrm{mg} / \mathrm{L}$ \\
\hline 5 & Copper as $\mathrm{Cu}$ & $28.3 \mathrm{mg} / \mathrm{L}$ \\
\hline 6 & Fluoride as F & $\begin{array}{l}\text { Below } \\
\text { Limit }\end{array}$ \\
\hline 7 & $\begin{array}{l}\text { Chromium } \\
\text { Hexavalent }\end{array}$ & $5721.95 \mathrm{mg} / \mathrm{L}$ \\
\hline
\end{tabular}

In this study ion exchange column is used to conduct fixedbed experiments to remove $\mathrm{Cr}(\mathrm{VI})$ from synthetic solution containing $150 \mathrm{mg} / \mathrm{L}$ of $\mathrm{Cr}(\mathrm{VI})$ and wastewater by using reconditioned anion exchange resin Tulsion A-27(MP). A glass column of internal diameter $1.04 \mathrm{~cm}$ is used as a fixedbed column. The air dried reconditioned and weighed resin is first placed in contact with distilled water in beaker for half an hour. The resin swells by absorbing water in pores. The wet resin or slurry is carefully transferred to glass column of diameter $1.04 \mathrm{~cm}$ and length $30 \mathrm{~cm}$ packed with glass wool at the bottom to retain resin in the column and clamped at the bottom end to control the required flow rate during column operations. After transferring all the resin to the column, the top end of the column is also packed with glass wool keeping a gap of $1 \mathrm{~cm}$ above packed resin bed filled with distilled water. The synthetic $\mathrm{Cr}(\mathrm{VI})$ solution and plating waste water of known concentration is stored in the reservoir for column experiments and is passed in down flow direction through the resin bed at constant flow rate by a rubber tube with clamp. The different parameters varied are mass of resin (bed-height), flow rate and influent $\mathrm{Cr}$ (VI) concentration. The initial concentration of $\mathrm{Cr}(\mathrm{VI})$ in the wastewater is reduced by appropriate dilution with distilled water. The concentration of $\mathrm{Cr}(\mathrm{VI})$ in influent and effluent after column operation is checked by di-phenylcarbazide (DPC) method. The $\mathrm{Cr}(\mathrm{VI})$ concentration in the effluent solution is analyzed spectrophotometrically by preparing a red-violet complex with acidic solution of acetone 1,5diphenyl carbazide as a complexing reagent. The absorbance is measured for the prepared red-violet colored complex at a wavelength of $540 \mathrm{~nm}$. For every deviation of absorbance values in this method, the $\mathrm{Cr}(\mathrm{VI})$ concentration is obtained by plotting the calibration curve of absorbance versus concentration. All the solutions are analyzed within 30 minutes after forming a complex.

Table-2: Properties of Tulsion A-27(MP) Resin

\begin{tabular}{|l|l|}
\hline Parameters & $\begin{array}{l}\text { Tulsion A-27(MP) } \\
\text { values }\end{array}$ \\
\hline Type & Strong base \\
\hline Matrix structure & Polystyrene copolymer \\
\hline Functional group & $\begin{array}{l}\text { Quaternary ammonium } \\
\text { type-1 }\end{array}$ \\
\hline Ionic form supplied & Chloride \\
\hline
\end{tabular}

\begin{tabular}{|l|l|}
\hline Screen size US mesh & $16-50$ \\
\hline $\begin{array}{l}\text { Partical mize mm } \\
\text { (minimum 95\%) }\end{array}$ & $0.3-1.2$ \\
\hline Stability max temp & $175 / 80$ \\
\hline pH range & $0-14$ \\
\hline $\begin{array}{l}\text { Total exchange capacity } \\
\text { (meq/ml.(min) }\end{array}$ & 1.2 \\
\hline $\begin{array}{l}\text { Backwash settled density } \\
\text { (lbs/cft)-g/l swelling\% }\end{array}$ & $\begin{array}{l}42-44 \\
670-710\end{array}$ \\
\hline $\begin{array}{l}\text { Reversible OH-g } \\
\text { approx }\end{array}$ & $58 \pm 3$ \\
\hline $\begin{array}{l}\text { Moisture content \% } \\
\text { approx }\end{array}$ & Pl \\
\hline
\end{tabular}

Features : Macroporous base Type-1 anion exchange resin with excellent physical And chemical stability and resistance to organic fauling.

Application: Multiple bed deionization, delalkalization and silica removal.

\subsection{Regeneration of Exhausted Tulsion A-27 (MP) Resin in Column}

After exhaustion of Tulsion A-27(MP) resin in the column regeneration of resin column is carried out by using different eluents. The regeneration is done by passing down flow of selected eluent solutions $2 \mathrm{M} \mathrm{HCl}$ and $2 \mathrm{M} \mathrm{NaCl}$ through the resin with a flow rate of $1 \mathrm{~mL} / \mathrm{min}$.

\section{RESULTS AND DISCUSSION}

\subsection{Column Study Data Analysis}

The time at which breakthrough occurs and the shape of the breakthrough curve are very important in column operation. Performance of column operation to remove metal from influent solution is evaluated through breakthrough curves. Adsorbed metal concentration is calculated from $\left(\mathrm{C}_{\mathrm{ad}}=\mathrm{C}_{0^{-}}\right.$ $\mathrm{C}_{\mathrm{t}}$ ) (where $\mathrm{C}_{0}=$ influent metal concentration, $\mathrm{C}_{\mathrm{t}}=$ effluent metal concentration) or normalized concentration $\left(\mathrm{C}_{\mathrm{t}} / \mathrm{C}_{0}\right)$ with respect to time or volume of effluent $\left(\mathrm{V}_{\text {eff }}=\mathrm{Qt}\right)$ for a given bed height [9]. Where $\mathrm{Q}$ is the volumetric Flow rate and $\mathrm{t}$ is the total flow time (min).

In the column the total adsorbed metal quantity (or maximum column capacity $=\mathrm{q}_{\text {total }} ; \mathrm{mg}$ ) for a given bed height (or resin quantity), influent concentration and Flow rate is calculated from the following equation:

$$
q_{\text {total }}=(Q / 1000) \int_{t=0}^{t=t_{\text {total }}} C_{a d} d t
$$

Here we calculated integration of $\mathrm{C}_{\mathrm{ad}}$ by mathematical numerical integration methods.

Total amount of metal sent $\left(\mathrm{m}_{\text {total }}\right)$ to column is calculated from the following equation:

$$
\mathrm{m}_{\text {total }}=\left(\mathrm{C}_{0} \times \mathrm{Q} \times \mathrm{t}_{\text {total }}\right) / 1000 .
$$


Total removal percentage is calculated from the following equation:

$$
\text { Total removal }(\%)=\left(\mathrm{q}_{\text {total }} / \mathrm{m}_{\text {total }}\right) \times 100 \text {. }
$$

The $\mathrm{q}_{\mathrm{eq}}$ (maximum capacity or Equilibrium metal uptake of the column the total amount of metal adsorbed per gram of

sorbent resin) at the end of total flow time is calculated by below given equation:

$$
\mathrm{q}_{\mathrm{eq}}=\left(\mathrm{q}_{\mathrm{total}} / \mathrm{X}\right)
$$

\subsection{Comparison between Reconditioned and Fresh Tulsion A-27(MP) resin for Cr(VI) removal by using}

\section{Influent Concentration- 150mg/L Synthetic Solution}

Table-3: Comparison between Reconditioned and Fresh Tulsion A-27(MP) resin for Cr(VI) removal by using influent concentration- $150 \mathrm{mg} / \mathrm{L}$ synthetic solution

\begin{tabular}{|l|l|l|l|l|l|l|l|l|}
\hline Resin Type & $\begin{array}{l}\mathrm{Z} \\
(\mathrm{cm})\end{array}$ & $\begin{array}{l}\mathrm{Q} \\
(\mathrm{mL} / \mathrm{min})\end{array}$ & $\begin{array}{l}\mathrm{C}_{0} \\
(\mathrm{mg} / \mathrm{L})\end{array}$ & $\begin{array}{l}\text { Total } \\
\text { time } \\
\mathrm{t}_{\text {total }} \\
(\mathrm{min})\end{array}$ & $\begin{array}{l}\mathrm{m}_{\text {total }} \\
(\mathrm{mg})\end{array}$ & $\begin{array}{l}\mathrm{q}_{\text {total }} \\
(\mathrm{mg})\end{array}$ & $\begin{array}{l}\mathrm{q}_{\mathrm{eq}} \\
(\mathrm{mg} / \mathrm{g})\end{array}$ & $\begin{array}{l}\text { Total metal } \\
\text { removal } \\
(\%)\end{array}$ \\
\hline $\begin{array}{l}\text { Reused Tulsion } \\
\text { A-27 (MP) resin }\end{array}$ & 2.8 & 1 & 150 & 1200 & 180 & 138.14 & 138.14 & 76.745 \\
\hline $\begin{array}{l}\text { Fresh Tulsion A- } \\
\text { 27(MP) resin }\end{array}$ & 2.8 & 1 & 150 & 1400 & 210 & 162.83 & 162.84 & 77.541 \\
\hline
\end{tabular}

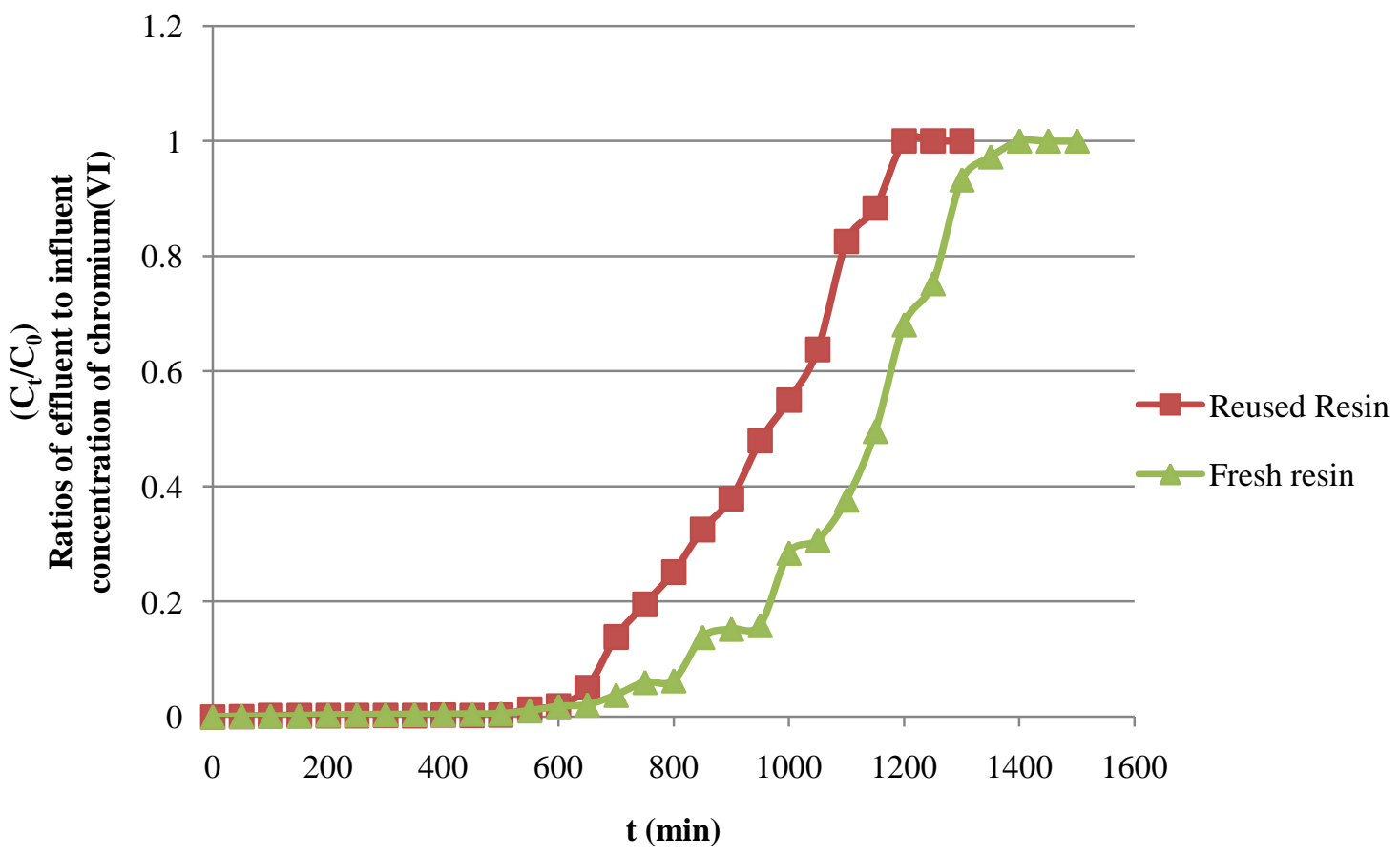

Fig-1: Breakthrough curves for Reconditioned and Fresh Tulsion A-27(MP) resin for Cr(VI) removal by using influent concentration- $150 \mathrm{mg} / \mathrm{L}$

From breakthrough curves and data obtained, fig-1 and table-3 the total percentage of metal removal by using reconditioned and fresh resin are almost same, which indicates that the reconditioned resin can be used for removal of $\mathrm{Cr}(\mathrm{VI})$. However, reconditioned resin gets exhausted more quickly than fresh resin. The total metal sent to the column is more in case of fresh resin due to higher exchange capacity of the resin. 
3.3 Variable Parameters Studied for Cr (VI) Removal from Wastewater by using Reconditioned Tulsion A27(MP) Resin

Table-4: The effect of Bed height of resin, flow rate and influent $\mathrm{Cr}(\mathrm{VI})$ concentration on the total adsorbed quantity of Cr(VI), equilibrium $\mathrm{Cr}(\mathrm{VI})$ uptake or maximum capacity of the column and total removal percentage of $\mathrm{Cr}(\mathrm{VI})$ from wastewater for adsorption to $\mathrm{Cr}(\mathrm{VI})$ onto Reconditioned Tulsion A-27(MP) resin

\begin{tabular}{|c|c|c|c|c|c|c|c|}
\hline $\begin{array}{l}\mathrm{Z} \\
(\mathrm{cm})\end{array}$ & $\begin{array}{l}\mathrm{Q} \\
(\mathrm{mL} / \mathrm{min})\end{array}$ & $\begin{array}{l}\mathrm{C}_{0} \\
(\mathrm{mg} / \mathrm{L})\end{array}$ & $\begin{array}{l}\text { Total time } \\
\mathrm{t}_{\text {total }}(\min )\end{array}$ & $\begin{array}{l}\mathrm{m}_{\text {total }} \\
(\mathrm{mg})\end{array}$ & $\begin{array}{l}\mathrm{q}_{\text {total }} \\
(\mathrm{mg})\end{array}$ & $\begin{array}{l}\mathrm{q}_{\mathrm{eq}} \\
(\mathrm{mg} / \mathrm{g})\end{array}$ & $\begin{array}{l}\text { Total metal } \\
\text { removal } \\
(\%)\end{array}$ \\
\hline \multicolumn{8}{|c|}{ Effect of Bed height } \\
\hline 2.8 & 1 & 1144.39 & 140 & 160.214 & 82.503 & 82.503 & 51.495 \\
\hline 5.6 & 1 & 1144.39 & 260 & 297.5414 & 190.016 & 95.0082 & 63.86 \\
\hline 14 & 1 & 1144.39 & 600 & 686.634 & 552.626 & 110.525 & 80.48 \\
\hline \multicolumn{8}{|c|}{ Effect of Flowrate } \\
\hline 5.6 & 1 & 1144.39 & 260 & 297.5414 & 190.016 & 95.0082 & 63.86 \\
\hline 5.6 & 2.5 & 1144.39 & 140 & 400.5365 & 162.908 & 81.4538 & 40.67232325 \\
\hline 5.6 & 5 & 1144.39 & 80 & 457.756 & 124.491 & 62.2453 & 27.19582048 \\
\hline \multicolumn{8}{|c|}{ Effect of initial concentration } \\
\hline 5.6 & 1 & 1144.39 & 260 & 297.5414 & 190.016 & 95.0082 & 63.86 \\
\hline 5.6 & 1 & 803.3 & 320 & 257.056 & 206.08 & 103.04 & 80.168874 \\
\hline
\end{tabular}

\subsubsection{Effect of bed height on the breakthrough}

\section{curve}

In order to carry out this investigation for the breakthrough curves at different bed heights $(2.8 \mathrm{~cm}, 5.6 \mathrm{~cm}$ and $14 \mathrm{~cm})$ and at influent $\mathrm{Cr}(\mathrm{VI})$ concentration $\left(\mathrm{C}_{0}=1144.39 \mathrm{mg} / \mathrm{L}\right)$ and Flowrate $(\mathrm{Q}=1 \mathrm{~mL} / \mathrm{min})$ for chromium $(\mathrm{VI})$ removal from wastewater on Reconditioned Tulsion A-27 (MP) resin, were plotted. The obtained results are shown in Fig-2 and Table-4. With increase in the column bed height, there is a increase in removal \% of $\mathrm{Cr}(\mathrm{VI})$ was observed for the employed resin. When the bed height increased, $\mathrm{Cr}(\mathrm{VI})$ had more surface area or sorption sites to contact with the Reconditioned Tulsion A-27 resin, hence this results increase in \% removal efficiency of $\mathrm{Cr}(\mathrm{VI})$ and higher metal uptake.

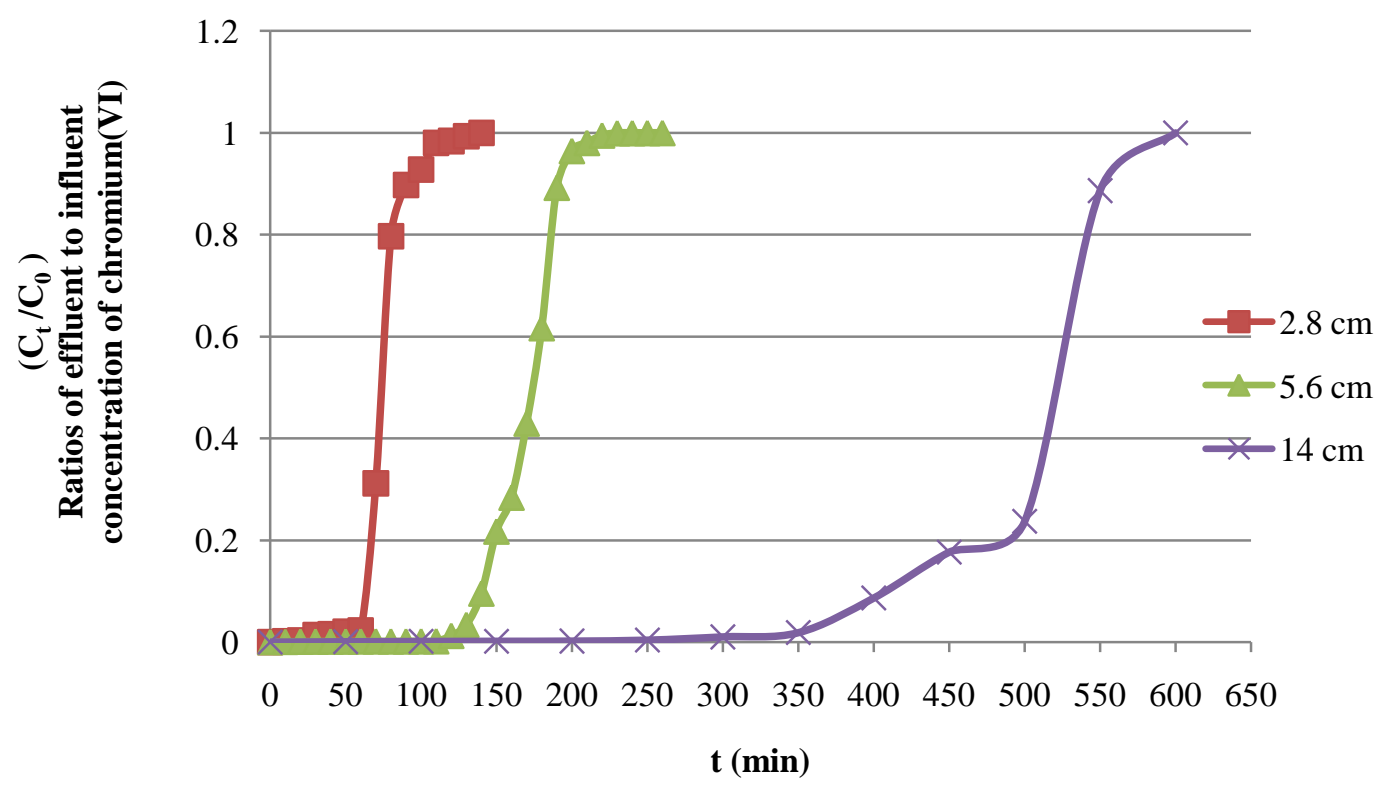

Fig-2: Breakthrough curves for chromium (VI) at different resin Bed height 


\subsubsection{Effect of Flow Rate on the Breakthrough} Curve

To investigate the effect of different Flow rates (1.0, 2.5 and $5.0 \mathrm{~mL} / \mathrm{min})$ on $\mathrm{Cr}(\mathrm{VI})$ removal at influent $\mathrm{Cr}(\mathrm{VI})$ concentration $1144.39 \mathrm{mg} / \mathrm{L}$ and bed height $5.6 \mathrm{~cm}$. The breakthrough curves for $\mathrm{Cr}(\mathrm{VI})$ on Reconditioned Tulsion
A-27(MP) resin were shown in Fig-2 and Table-4. It is seen that the time required for breakthrough is less as we increase the flow rate from $1 \mathrm{ml} / \mathrm{min}$ to $5 \mathrm{ml} / \mathrm{min}$. With decrease in flow rate the contact time of influent with resin is more which results in higher percentage removal of $\mathrm{Cr}(\mathrm{VI}) .63 .8$ $\%$ removal of $\mathrm{Cr}$ (VI) is observed at flow rate of $1 \mathrm{ml} / \mathrm{min}$ as represented in Table-4.

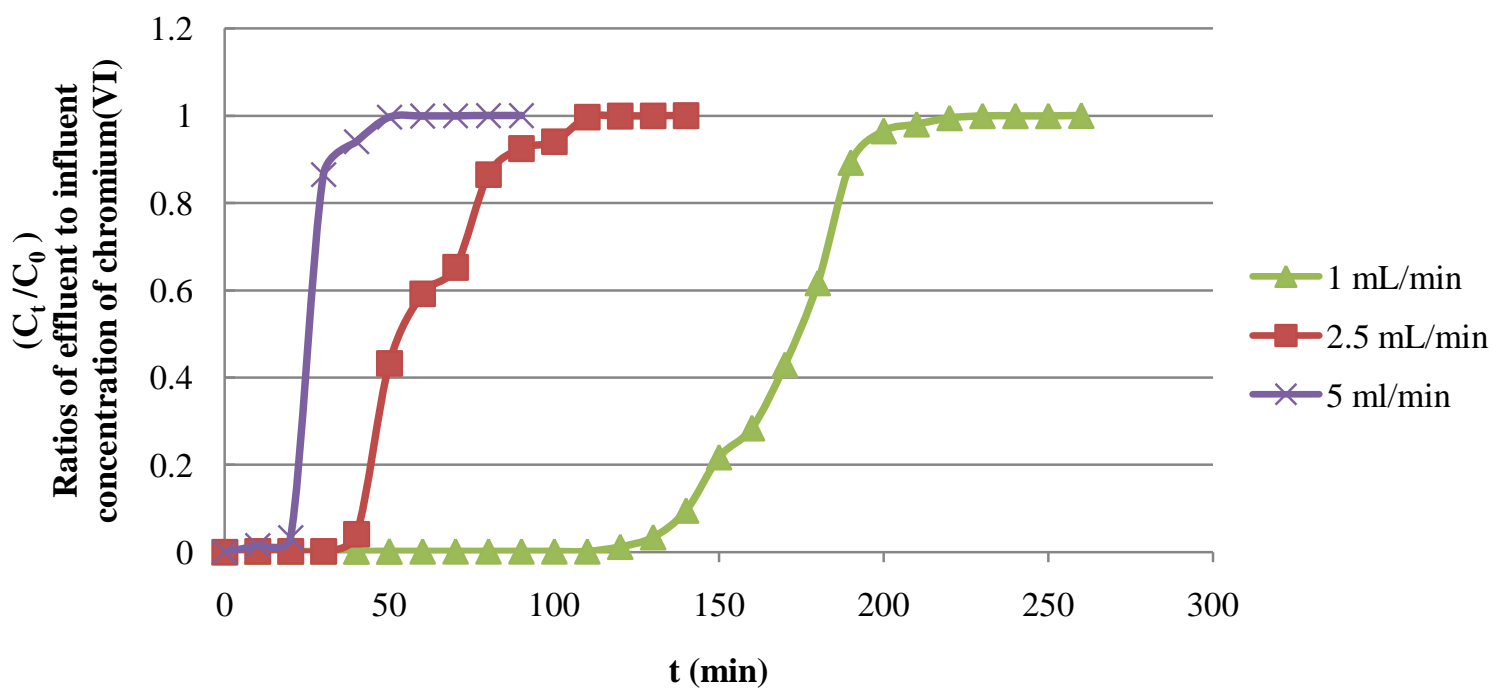

Fig-3: Breakthrough curves for chromium(VI) at different Flowrates

\subsubsection{Effect of Influent Cr (VI) Concentration on Breakthrough Curves}

The breakthrough curves for chromium (VI) at different influent $\mathrm{Cr}(\mathrm{VI})$ concentrations are shown in fig-4 at bed height $5.6 \mathrm{~cm}$ and flow rate $1 \mathrm{~mL} / \mathrm{min}$. The results obtained are represented in table-4. It is observed that with increase in influent $\mathrm{Cr}(\mathrm{VI})$ ion concentration from 803.30 to
$1144.39 \mathrm{mg} / \mathrm{L}$ there is a decrease in breakthrough time which results increase in $\mathrm{Cr}(\mathrm{VI})$ removal \%. This is because of the lower mass-transfer flux due to weaker driving force. The availability of metal $\mathrm{Cr}(\mathrm{VI})$ ions for the sorption sites is more at higher concentration hence this leads to higher $\mathrm{Cr}(\mathrm{VI})$ uptake even though the breakthrough time is shorter than at lower initial $\mathrm{Cr}(\mathrm{VI})$ concentration.

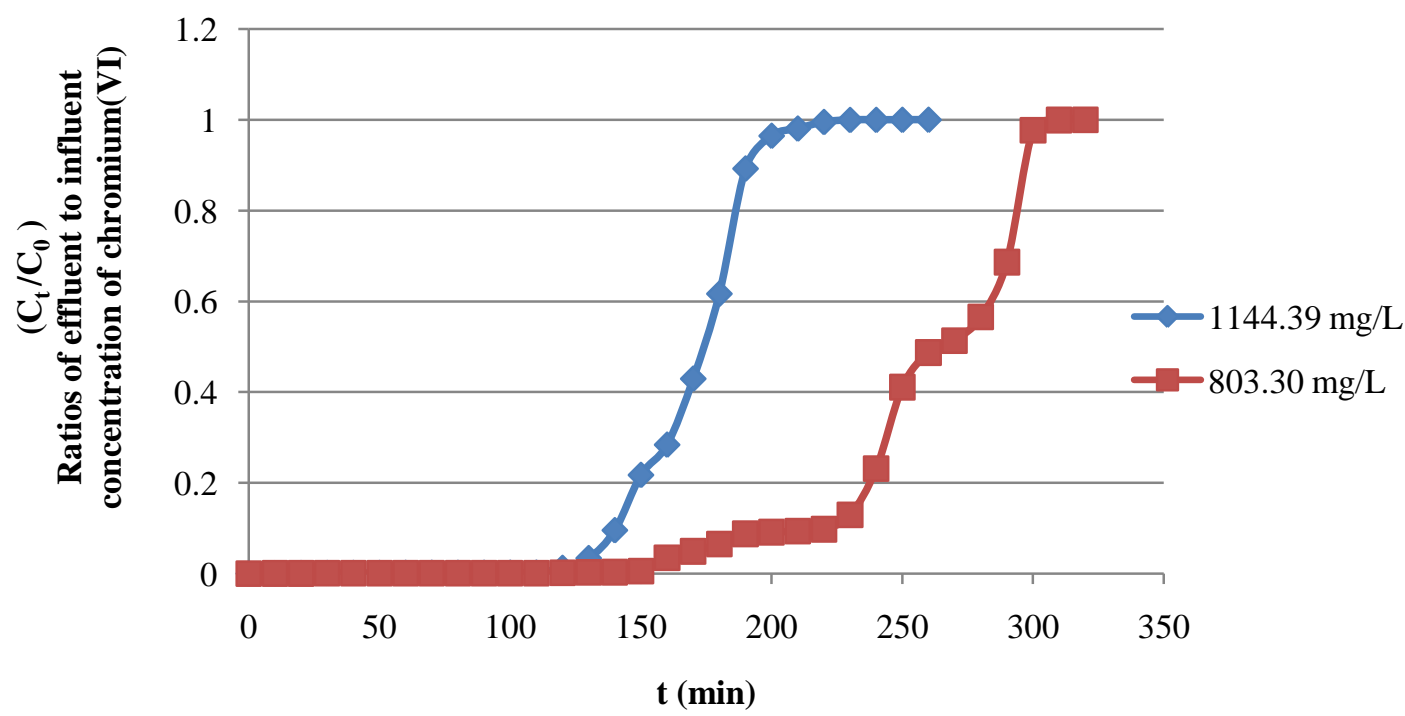

Fig-4: Breakthrough curves for chromium (VI) at different influent $\mathrm{Cr}(\mathrm{VI})$ concentrations 


\subsection{Modeling of Breakthrough Curves for Bohart-}

\section{Adams Model}

\subsubsection{The Bohart-Adams Model}

Bohart-Adams model assumes that equilibrium is not instantaneous based on the surface reaction theory; hence, the sorption is proportional to the fraction of sorption capacity which will remain on the sorbent resin. This model introduced the prime equations gives the description of the relationship in a continuous system between $\left(\mathrm{C}_{\mathrm{t}} / \mathrm{C}_{0}\right)$ and time $(\mathrm{t})$. The Bohart-Adams model is applied to describe the beginning or starting part of the breakthrough curve. This approaching action focused on the determination of characteristic parameters are maximum sorption capacity of sorbent $\left(\mathrm{N}_{0}\right)$ and Bohart-Adams rate constant $\left(\mathrm{k}_{\mathrm{AB}}\right)$ [9][10] using a below given kinetic rate expression:
Where, $\mathrm{C}_{0}(\mathrm{mg} / \mathrm{L})$ is the influent $\mathrm{Cr}(\mathrm{VI})$ concentration and $\mathrm{C}_{\mathrm{t}}$ $(\mathrm{mg} / \mathrm{L})$ is effluent $\mathrm{Cr}(\mathrm{VI})$ concentration. $\mathrm{k}_{\mathrm{AB}}(\mathrm{L} / \mathrm{mg} \cdot \mathrm{min})$ is the Bohart-Adams rate constant, $\mathrm{U}_{0}(\mathrm{~cm} / \mathrm{min})$ is the linear velocity $\left(\mathrm{U}_{0}=\mathrm{Q} / \mathrm{A}, \mathrm{Q}=\right.$ Flowrate; $\mathrm{A}=$ column section area), bed depth of column $\mathrm{Z}(\mathrm{cm})$ and $\mathrm{N}_{0}(\mathrm{mg} / \mathrm{L})$ is capacity of the sorbent. The $\mathrm{t}(\mathrm{min})$ is the time should be considered from the starting to the end of breakthrough.

From linear plot of $\ln \left(\mathrm{C}_{\mathrm{t}} / \mathrm{C}_{0}\right)$ against $(\mathrm{t})$ time the intercept and slope obtained to calculate the $\mathrm{N}_{0}$ and $\mathrm{k}_{\mathrm{AB}}$ values. Respective values of $\mathrm{N}_{0}$ and $\mathrm{k}_{\mathrm{AB}}$ were determined and summarized in Table-5. with their respective correlation coefficients.

$\ln \left(\mathrm{C}_{\mathrm{t}} / \mathrm{C}_{0}\right)=\mathrm{k}_{\mathrm{AB}} \mathrm{C}_{0} \mathrm{t}-\left(\mathrm{k}_{\mathrm{AB}} \mathrm{N}_{0}\left(\mathrm{Z} / \mathrm{U}_{0}\right)\right)$

Table-5: Bohart-Adams model parameters using linear regression analysis for $\mathrm{Cr}(\mathrm{VI})$ adsorption from wastewater onto Reconditioned Tulsion A-27(MP) resin under various operating conditions or at different "Bed heights of resin, Influent $\mathrm{Cr}(\mathrm{VI})$ concentration and flow rate"

\begin{tabular}{|l|l|l|l|l|l|l|}
\hline $\begin{array}{l}\text { Bed height } \\
\mathrm{Z}(\mathrm{cm})\end{array}$ & $\begin{array}{l}\text { Flow rate } \\
\mathrm{Q}(\mathrm{mL} / \mathrm{min})\end{array}$ & $\begin{array}{l}\text { Influent Cr(VI) } \\
\text { concentration } \\
\mathrm{C}_{0}(\mathrm{mg} / \mathrm{L})\end{array}$ & $\begin{array}{l}\text { Bohart-Adams rate } \\
\text { constant } \\
\mathrm{k}_{\mathrm{AB}}\left(\times 10^{-5} \mathrm{~L} \mathrm{mg}^{-1}\right. \\
\mathrm{min}^{-1}\end{array}$ & $\begin{array}{l}\text { Capacity of the } \\
\text { sorbent } \\
\mathrm{N}_{0}(\mathrm{mg} / \mathrm{L})\end{array}$ & $\mathrm{R}^{2}$ \\
\hline 2.8 & 1 & 1144.39 & 4.718 & 55694.798 & 0.857 \\
\hline 5.6 & 1 & 1144.39 & 3.3205 & 54162.88 & 0.895 \\
\hline 14 & 1 & 1144.39 & 1.1223 & 58882.95 & 0.973 \\
\hline 5.6 & 2.5 & 1144.39 & 4.5439 & 26300.016 & 0.688 \\
\hline 5.6 & 5 & 1144.39 & 3.8934 & 15048.077 & 0.605 \\
\hline 5.6 & 1 & 803.30 & 3.859 & 50195.67 & 0.946 \\
\hline
\end{tabular}

Bohart-Adams rate constant, $\mathrm{k}_{\mathrm{AB}}$ and capacity of sorbent $\left(\mathrm{N}_{0}\right)$ depends on flow rate, influent $\mathrm{Cr}(\mathrm{VI})$ concentration and bed height. From Table-5, it can be seen that the Capacity of the sorbent is maximum at lower flow rate and higher bed height as expected. Figures 5, 6 and 7. represent the linear plots of Bohart- Adam model. High correlation coefficient for bed height $14 \mathrm{~cm}$ and influent flow rate $1 \mathrm{~mL} / \mathrm{min}$ indicate that Bohart-Adams model is appropriate predictor for the breakthrough curves for field systems. 


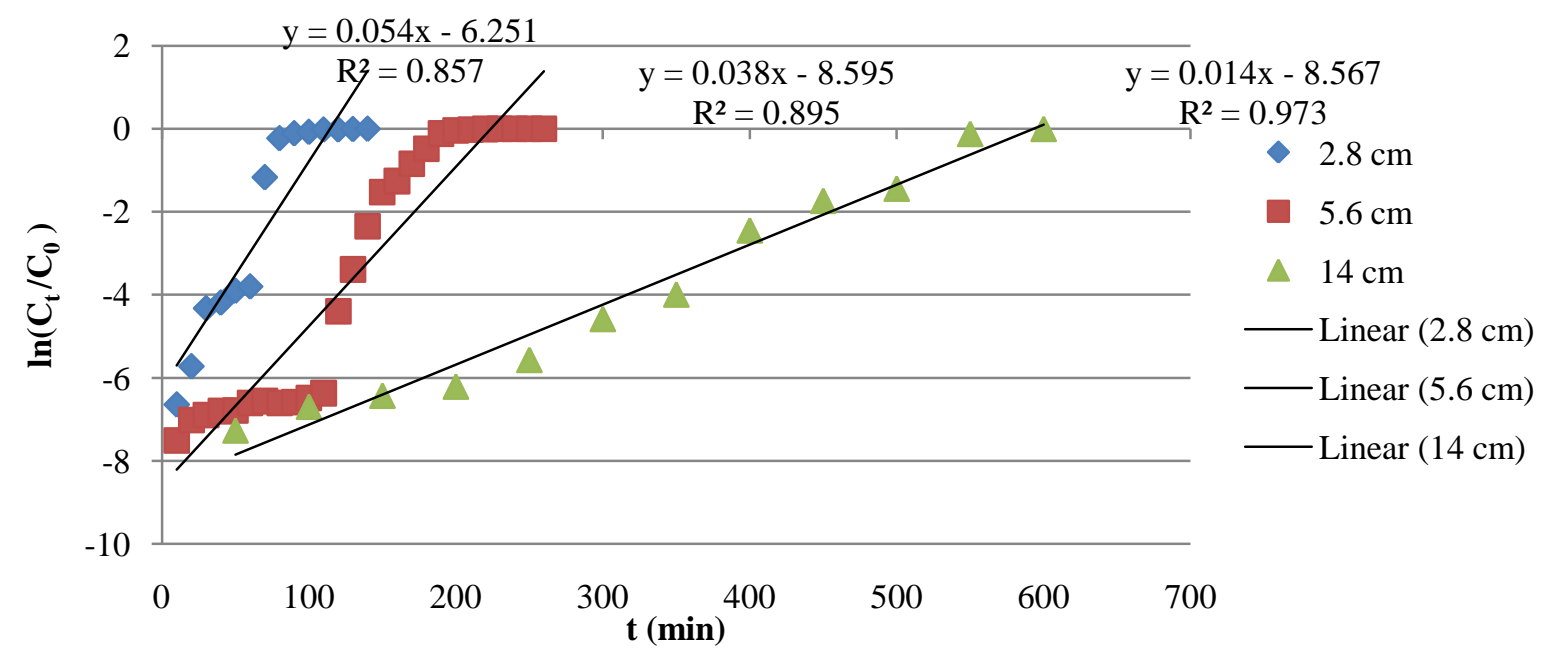

Fig-5: "Linear plot of Bohart-Adams model with experimental data at different bed heights"

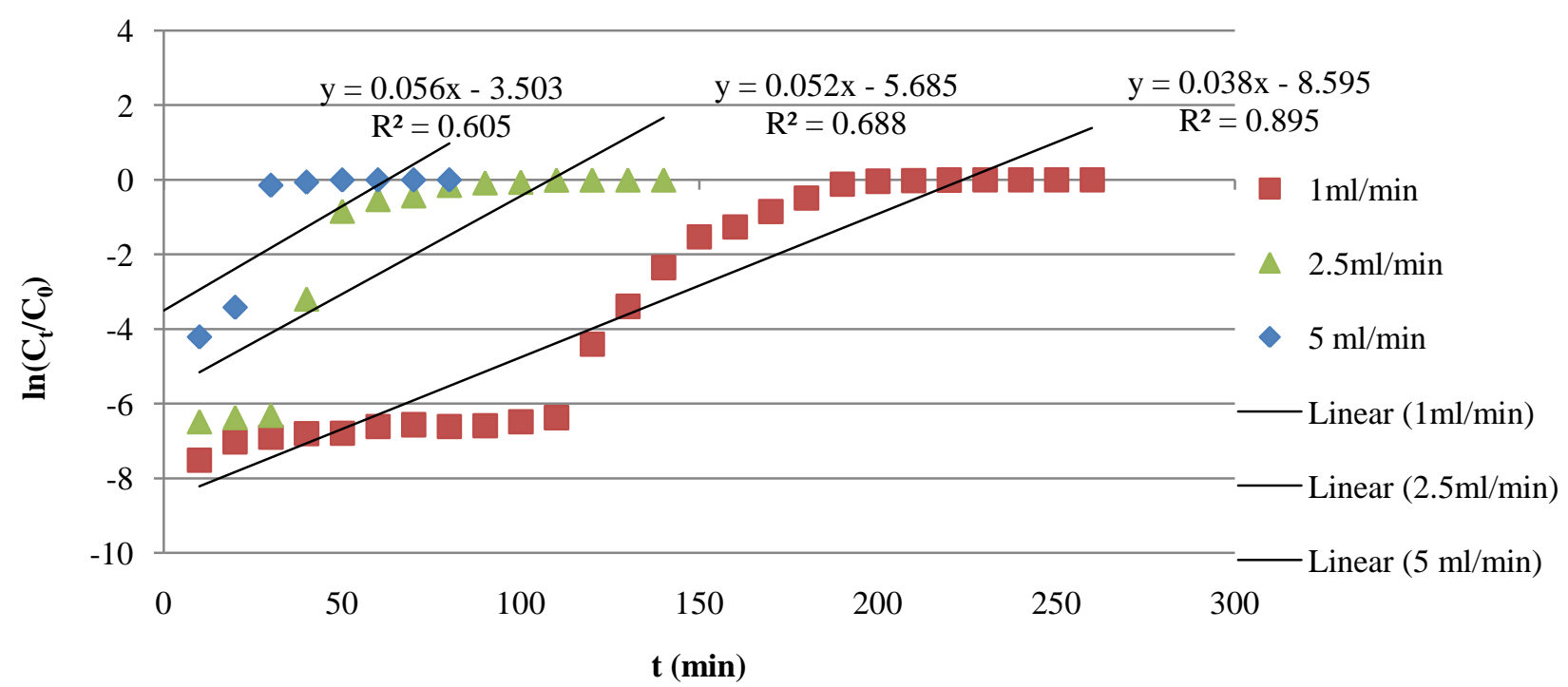

Fig-6: "Linear plot of Bohart-Adams model with experimental data at different flowrates"

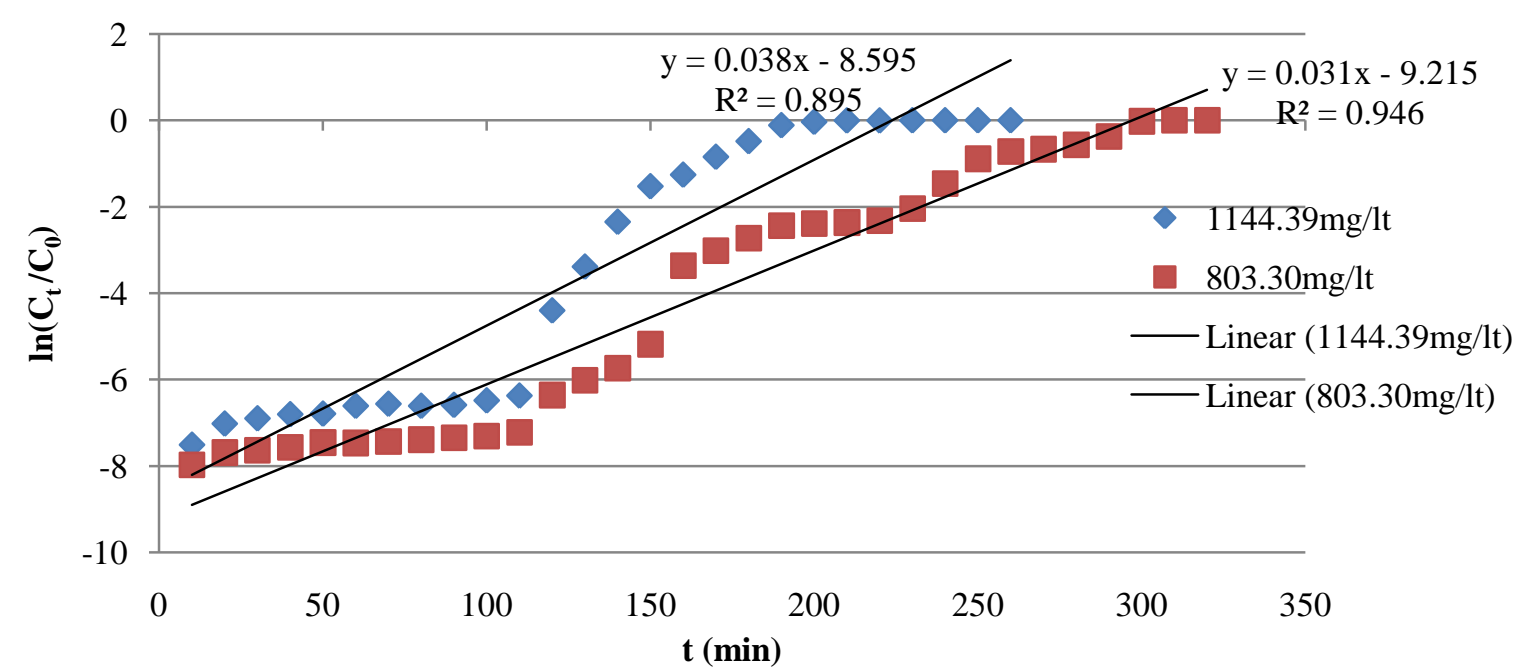

Fig-7: "Linear plot of Bohart-Adams model with experimental data at different influent $\mathrm{Cr}(\mathrm{VI})$ concentrations" 


\subsection{Comparative Study of Reconditioned and Fresh Tulsion A-27(MP) resin for Cr(VI) Removal from}

\section{Wastewater}

Table-6: Comparative study of Reconditioned and Fresh Tulsion A-27(MP) resin for Cr(VI) removal from wastewater"

\begin{tabular}{|l|l|l|l|l|l|l|l|l|}
\hline $\begin{array}{l}\text { Bed } \\
\text { height } \\
\mathrm{Z}(\mathrm{cm})\end{array}$ & $\begin{array}{l}\text { Flowrate } \\
\mathrm{Q}(\mathrm{mL} / \mathrm{min})\end{array}$ & $\begin{array}{l}\text { Initial } \\
\text { concentration } \\
\mathrm{C}_{0}(\mathrm{mg} / \mathrm{L})\end{array}$ & $\begin{array}{l}\text { Total time } \\
\mathrm{t}_{\text {tota }}(\mathrm{min})\end{array}$ & $\begin{array}{l}\text { Total amount of } \\
\text { metal ion sent } \\
\text { to column } \\
\mathrm{m}_{\text {total }}(\mathrm{mg})\end{array}$ & $\begin{array}{l}\text { Total } \\
\text { adsorbed } \\
\text { metal } \\
\text { quantity } \\
\mathrm{q}_{\text {total }}(\mathrm{mg})\end{array}$ & $\begin{array}{l}\text { Maximum } \\
\text { capacity of the } \\
\text { column } \\
\mathrm{q}_{\mathrm{eq}}(\mathrm{mg} / \mathrm{g})\end{array}$ & $\begin{array}{l}\text { Total } \\
\text { metal } \\
\text { removal } \\
(\%)\end{array}$ \\
\hline $14 \mathrm{~cm}$ & 1 & 1144.39 & 600 & 686.634 & 552.626 & 110.525 & 80.4833 \\
\hline $14 \mathrm{~cm}$ & 1 & 1144.39 & 650 & 743.85 & 607.394 & 121.48 & 81.655 \\
\hline
\end{tabular}

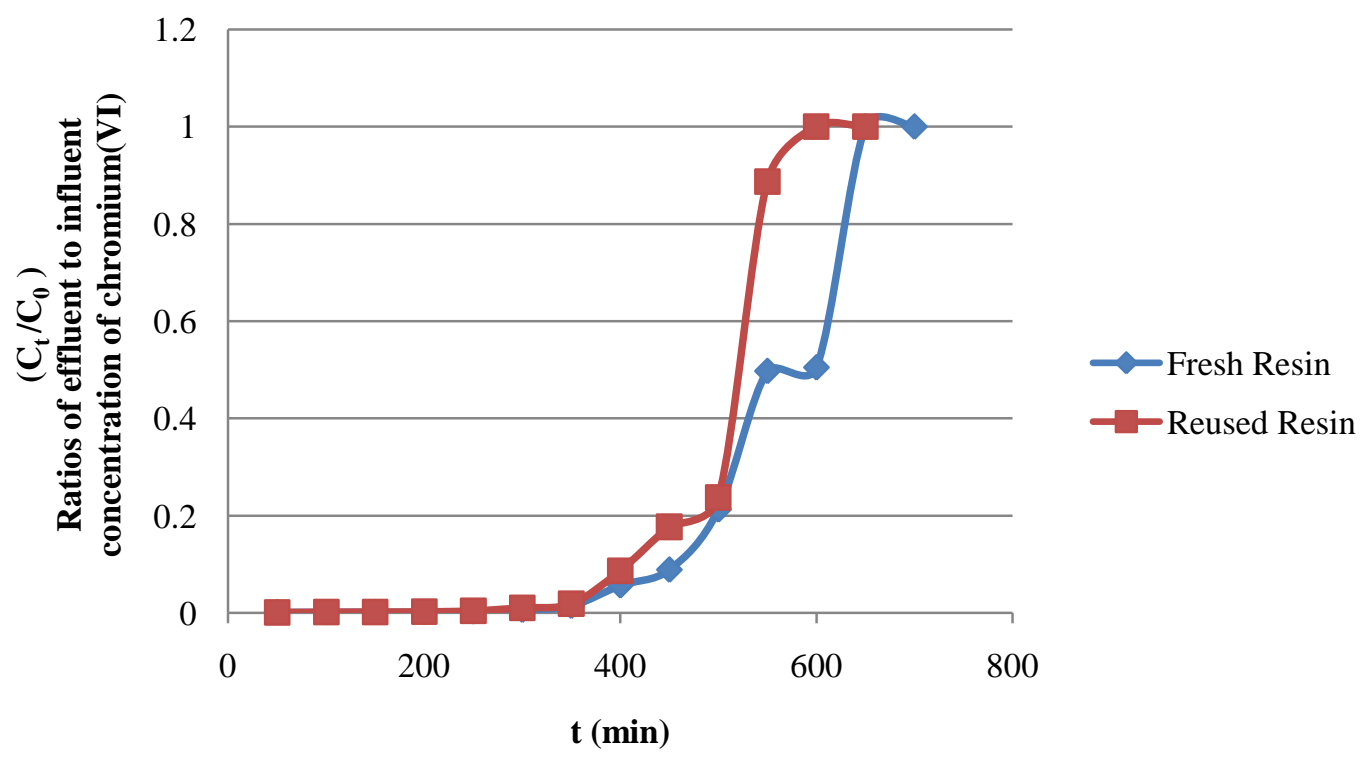

Fig-8: "Breakthrough curves for chromium(VI) removal from wastewater at Reconditioned and Fresh Tulsion A-27(MP) Resin"

From Table-6 and Fig-8 results we can say that the adsorbed metal quantity more in case of fresh resin than that of Reconditioned Tulsion A-27(MP) resin due to higher exchange capacity of fresh resin. This is mainly because exchange sites available for sorption are less for Reconditioned resin as the resins used earlier number of times for removal of $\mathrm{Cr}(\mathrm{VI})$ by batch process.

\subsection{Regeneration of Exhausted Reconditioned Tulsion A-27(MP) Resin with Different Eluents}

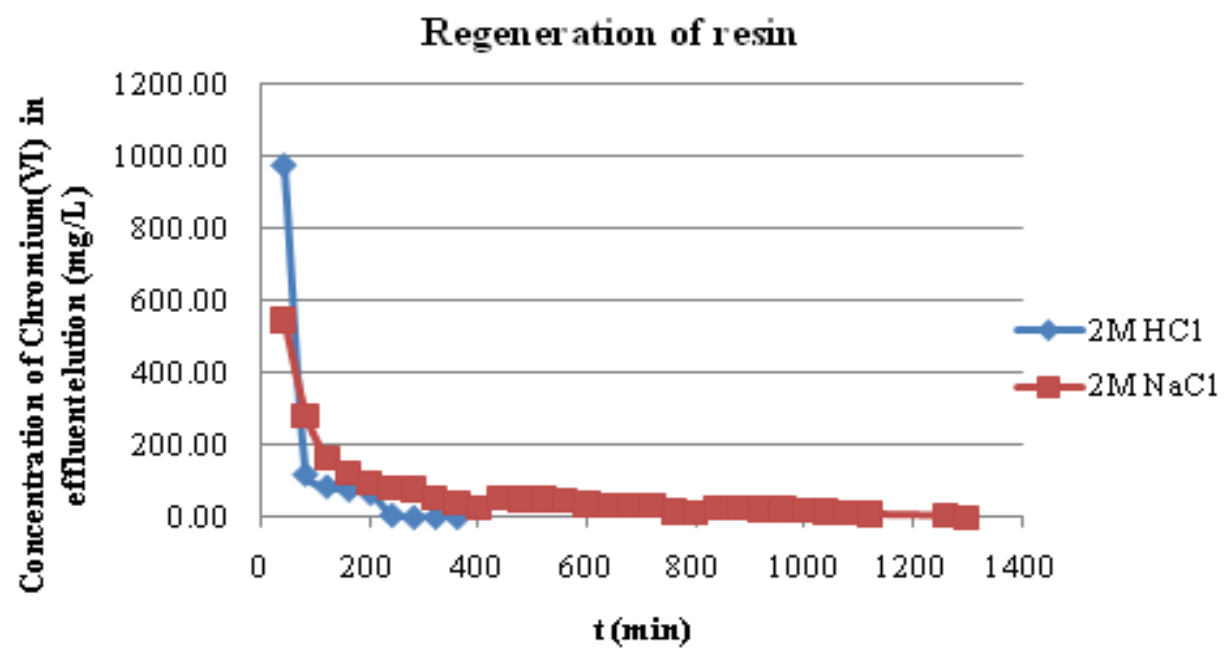

Fig-9: Regeneration of 1gm Reconditioned Tulsion A-27(MP) resin with $2 \mathrm{M} \mathrm{HCl}$ and $2 \mathrm{M} \mathrm{NaCl}$ eluents 
Fig-9 shows that the highest $\mathrm{Cr}(\mathrm{VI})$ concentration in the effluent was observed after passing $40 \mathrm{~mL}$ of $2 \mathrm{M} \mathrm{HCl}$ and $2 \mathrm{M} \mathrm{NaCl}$ through the column as an eluent, After that the concentration of $\mathrm{Cr}$ (VI) gradually decreased until zero concentration. The regeneration of resin was rapid with $2 \mathrm{M}$ $\mathrm{HCl}$ but it is observed that the effluent coming out of the column was green coloured with precipitate. However there is no precipitate formation and green colour of effluent with $2 \mathrm{M} \mathrm{NaCl}$ eluent. The results indicate that $2 \mathrm{M} \mathrm{NaCl}$ is more appropriate eluent for regeneration. The green colour of the effluent may be due to reduction of $\mathrm{Cr}(\mathrm{VI})$ to $\mathrm{Cr}$ (III) state.

The mechanism of elution of chromate with $2 \mathrm{M} \mathrm{HCl}$, and $2 \mathrm{M} \mathrm{NaCl}$

$$
\begin{gathered}
\mathrm{HCl}+\mathrm{RHCrO}_{4} \rightarrow \mathrm{RCl}+\mathrm{H}_{2} \mathrm{CrO}_{4} \\
2 \mathrm{NaCl}+\mathrm{RHCrO}_{4} \rightarrow \quad \mathrm{RCl}+\mathrm{Na}_{2} \mathrm{CrO}_{4}+\mathrm{HCl}
\end{gathered}
$$

\section{CONCLUSION}

Chromium (VI) from Chrome plating wastewater can be efficiently removed by using reconditioned and fresh Tulsion A-27 ( MP) resins by ion exchange column process. Ion exchange column operations and breakthrough curves obtained at different flow rate, bed height and influent concentration clearly indicate, higher the bed height of resin and lower the flow rate and influent $\mathrm{Cr}(\mathrm{VI})$ concentration favors the separation of $\mathrm{Cr}(\mathrm{VI})$. Percentage removal of $\mathrm{Cr}(\mathrm{VI})$ is found to be 80.485 for waste water for bed height $14 \mathrm{~cm}$, flow rate $1 \mathrm{~mL} / \mathrm{min}$ and influent concentration $1144.39 \mathrm{mg} / \mathrm{L}$ of $\mathrm{Cr}(\mathrm{VI})$. Comparative study of fresh and reconditioned Tulsion A-27 (MP) resins used for column operations indicate that Strong base reconditioned anion exchange resins are suitable for $\mathrm{Cr}(\mathrm{VI})$ removal which results in recycling of used resin. Regeneration of exhausted Tulsion A-27 (MP) resin is more feasible with $2 \mathrm{M} \mathrm{NaCl}$ than $2 \mathrm{M} \mathrm{HCl}$.

\section{ABBREVIATIONS}

$\mathrm{Z}=$ Bed height of Resin, $(\mathrm{cm})$

$\mathrm{Q}=$ Flowrate, $(\mathrm{mL} / \mathrm{min})$

$\mathrm{C}_{0}=$ Influent $\mathrm{Cr}(\mathrm{VI})$ concentration, $(\mathrm{mg} / \mathrm{L})$

$\mathrm{C}_{\mathrm{ad}}=$ Adsorbed metal concentration, $(\mathrm{mg} / \mathrm{L})$

$\mathrm{C}_{\mathrm{t}}=$ Effluent Concentration of $\mathrm{Cr}(\mathrm{VI}),(\mathrm{mg} / \mathrm{L})$

$\mathrm{q}_{\mathrm{total}}=$ Total adsorbed metal quantity, $(\mathrm{mg})$

$\mathrm{m}_{\text {total }}=$ Total amount of metal ion sent to column, (mg)

$\mathrm{t}_{\text {total }}=$ Total time, $(\mathrm{min})$

$\mathrm{q}_{\mathrm{eq}}=$ Maximum capacity of the column, $(\mathrm{mg} / \mathrm{g})$

$\mathrm{N}_{0}=$ Capacity of the sorbent, $(\mathrm{mg} / \mathrm{L})$

$\mathrm{k}_{\mathrm{AB}}=$ Bohart-Adams rate constant, $(\mathrm{L} / \mathrm{mg} \min )$

$\mathrm{U}_{0}=$ Linear velocity, $(\mathrm{cm} / \mathrm{min})$

$\mathrm{R}^{2}=$ correlation coefficient or Regression coefficient

\section{REFERENCES}

[1] CHEN Ji, GUO Lin, YANG Xiu-yun1, ZHANG Jian-ping, ZHAO He, ZHANG Yang., (2012). Solvent impregnated resin prepared using ionic liquid Cyphos IL 104 for Cr(VI) removal. Trans.Nonferrous Met. Soc. China 22(2012) 3126-3130.
[2] Aronov.L, Belayev.N, Korngold.E., (2003). Removal of chromates from drinking water by anion exchangers. Separation of Purification Technogy 33(2003) 179-187.

[3] Jun SHI, Mei-ling KONG, Xiao-ou MA. (2011). The Adsorption of CHS-1 Resin for Cr(VI) of low concentration from Electroplating wastewater.Sciverse Sci.direct Procedia Engineering 18 (2011) 116-121.

[4] Babu.B.V, Suresh Gupta. (2010). Experimental investigations and Theoretical Modeling Aspects in Column studies for Removal of $\mathrm{Cr}(\mathrm{VI})$ from Aqueous Solutions using Activated Tamrind Seeds. J.Water Resource and Protection, 2010, 2, 706-716.

[5] Anabarasu.V, Nilanjana Das, Vinodini.V. (2010).Screening of natural waste products for the removal of $\mathrm{Cr}$ (VI) ions from industrial effluents. Indian Journal of Natural Products and Resources Vol. 1(2), June 2010, pp. 174-180.

[6] Khalid Z. Elwakeel. (2010). Removal of $\mathrm{Cr}$ (VI) from Alkaline Aqueous solutions using chemically Modified Chitosan Resins. Fourteenth International Water Technology Conference, IWTC 14 2010, Cairo, Egypt.

[7] Arshad Husain, Iram Javed and Nadeem Ahmad Khan., (2014). Characterization and treatment of electroplating industry wastewater using Fenton's reagent. 2014, 6(1):622-627 ISSN:09757384.CODEN(USA):JCPRC5.

[8] Bhechir Hamrouni, Chiraz Hannachi, Fatma Guesmi, Khaoula Missaoui, Hana Tounakti.,(2013). Ion Exchange equilibrium between DOWEX 1X8 Resin modified by Polyethyleneimine and Electrolyte Solutions. Journal of Water Resource and Protection, 2013, 5, 1059-1065.

[9] Emine Malkot,Murat Dundar,Yasar Nuhoglu., (2006). Adsorption of chromium(VI) on promace-An olive oil industry waste: Batch and column studies. Journal of Hazardous Materials B138 (2006) 142151.

[10] Mohamed A.Mahamoud., (2015). Kinetics studies of uranium sorption by powdered corn cob in batch and fixed bed system. Journal of Advanced Research, 2015. 